\title{
Behaviour of interlocking mortarless hollow block walls under in-plane loading
}

\begin{abstract}
Experimental study of five full scale masonry wall panels subjected to prescibed precompressive vertical loading and increasing in-plane lateral loading is discussed. All five walls were constructed using interlocking mortarless load bearing hollow concrete blocks. The behaviour of wall in term of deflections along the wall height, shear strength, mortarless joint behaviour and local and overall failures under increasing in-plane lateral loading and precompressive vertical loading are reported and analysed. Simple strut-and-tie models are also developed to estimate the ultimate in-plane lateral capacity of the panel walls tested. The results indicate that, as the pre-compressive load increases, the in-plane lateral load capacity of walls increases. All walls tested failed due to diagonal shear and/or moderate toe crushing depending on the level of the pre-compressive load. The proposed strut-and-tie models were able to give reasonable predictions of the walls tested.
\end{abstract}

Keyword: In-plane loading; Shear strength; Mortarless masonry; Dry joint; Putra block; Hollow block; Strut-and-tie model 